\title{
1 Neev, a novel long non-coding RNA, is expressed in chaetoblasts during regeneration of \\ 2 Eisenia fetida
}

Surendra Singh Patel ${ }^{1,2}$, Sanyami Zunjarrao ${ }^{3}$, Beena Pillai ${ }^{1,2}$

${ }^{1}$ CSIR-Institute of Genomics and Integrative Biology, Delhi, 110025

$7 \quad{ }^{2}$ Academy of Scientific \& Innovative Research (AcSIR)

$8{ }^{3}$ Institute of Bioinformatics and Biotechnology, Savitribai Phule Pune University, Pune

Corresponding author's e-mail address: beena@igib.in

Running title: Novel IncRNA of regenerating earthworm

Summary statement: The earthworm, Eisenia fetida, regenerates posterior segments following amputation. The transcriptome of the regenerating worm revealed a novel IncRNA, expressed only at the base of regenerating chaetae. We propose that this IncRNA is a miRNA sponge that modulates chitin synthesis.

\section{Abstract:}

Eisenia fetida, the common vermicomposting earthworm, shows robust regeneration of posterior segments removed by amputation. During the period of regeneration, the newly formed tissue initially contains only undifferentiated cells but subsequently differentiates into a variety of cell types including muscle, nerve and vasculature. Transcriptomics analysis, reported previously, provided a number of candidate non-coding RNAs that were induced during regeneration. We found that one such long non-coding RNA (IncRNA) is expressed in the skin, only at the base of newly formed chaetae. The spatial organization and precise arrangement of the regenerating chaetae and the cells expressing the IncRNA on the ventral side clearly support a model wherein the regenerating tissue contains a zone of growth and cell division at the tip and a zone of differentiation at the site of amputation. The temporal expression pattern of the IncRNA, christened Neev, closely resembled the pattern of chitin synthase genes, implicated in chaetae

31 formation. We found that the IncRNA harbours 49 sites for binding a set of four miRNAs while the

32 Chitin Synthase 8 mRNA comprises 478 sites. The over-representation of shared miRNA sites

33 suggests that IncRNA Neev may act as a miRNA sponge to transiently de-repress chitin synthase

348 during formation of new chaetae in the regenerating segments of Eisenia fetida. 


\section{Introduction:}

Earthworms are a large diverse group of segmented worms that inhabit niches just under or deep within the soil. The tube within a tube body plan of the earthworm comprises a muscular outer wall enclosing a gut within. It also has a simple vascular system to circulate blood and a nervous system comprising a nerve ganglion at the anterior end and a long ventral nerve cord running the length of the body and ring nerves within each segment.

Earthworms vary widely in their ability to regenerate. Eisenia fetida (commonly known as red wriggler) regenerates nearly $2 / 3 r d$ of its posterior end (Xiao et al., 2011). The earthworm presents an invertebrate model of epimorphosis, a type of regeneration involving the restoration of original anatomy and polarity followed by de-differentiation, proliferation and differentiation of cells (Bely, 2014; Gazave et al., 2013; Planques et al.). Since each segment consists of nerve, muscle, vasculature and additional specialized structures, it provides a model for studying regeneration coordinated across different tissue types. For instance, chaetae, specialized projections embedded in the skin used for gripping the soil are controlled by nerves in each segment to achieve a well-coordinated crawl.

We have previously characterized the genome and transcriptome of the regenerating earthworm

54 (Bhambri et al., 2018). Injury and loss of posterior 2/3rd of Eisenia fetida was followed by apparent wound healing in 5-10 days. A stub of tissue largely consisting of a mass of undifferentiated tissue was formed by 15 days and differentiated segments were formed by 20 days post-amputation. The period between 10 to 20 days after the injury presents a time window during which cell proliferation, growth and differentiation happens simultaneously in a $4-5 \mathrm{~mm}$ long tissue amenable to molecular and cellular visualization.

The transcriptome of the regenerating worm revealed signatures of rapid cell proliferation, reorganization of extracellular matrix and the differentiation of nerves. Besides these signatures,

63 we also reported the dynamic expression of non-coding RNAs that potentially play roles in 64 regulating the timely, controlled and spatially organized transcriptome (Bhambri et al., 2018).

65 Here, we report the expression pattern of selected non-coding RNAs in the regenerating 66 earthworm. Besides validating our previous report, we focus on an IncRNA, which showed a 67 unique expression pattern at the base of the chaetae. 
69 Chaetae are stiff chitinous structures (appendages) that originate deep within the muscular body

70 wall, the outer ends of which are used to grip the surface and in locomotor activity (Hausen, 2005).

71 The IncRNA, named Neev, is expressed only in the few cells at the base of chaetae in newly

72 regenerated segments close to the site of injury. Its expression pattern closely resembles that of

73 chitin synthase and chitinases involved in the formation of chaetae. Most importantly, the position

74 of chaetae and the expression pattern of Neev support a model wherein the rapidly proliferating

75 cells are restricted to the tip while the zone of differentiation is established close to the injury site

76 (Gazave et al., 2013). Notably, Neev is not expressed at the base of the pre-existing chaetae.

77 Clearly the IncRNA is spatially restricted to a few cells and expressed transiently during the

78 formation of chaetae, but it is not required for its maintenance or function.

\section{Materials and Methods:}

Experimental conditions: Eisenia fetida earthworms were originally procured from farmers engaged in vermicomposting and has been subsequently maintained in a plastic tray and fed with plant matter in the laboratory at around $22^{\circ} \mathrm{C}$ for several years. No specific permissions were required for procuring earthworms. They are not included in lists of endangered species and do not come under animals requiring ethical approval. Medium sized worms were collected before the experiment, rinsed in tap water to remove any soil sticking to the surface and amputated as described in our previous paper (Bhambri et al., 2018). The site of amputation was at about 2/3rd of the body length from the anterior end, thus retaining about 60 segments. After amputation, the worms were maintained in a separate container but under similar culture conditions. Regenerating tissue and about $2-3 \mathrm{~mm}$ of the adjacent tissue from the pre-amputated worms were collected for

92 in situ hybridization.

RNA isolation and probe designing: The regenerated earthworm was rinsed thoroughly in running tap water followed by autoclaved milli-Q water, regenerated and adjacent control tissue from 20-30 earthworms was collected in $1 \mathrm{ml}$ Trizol kept on ice, respectively at 15, 20- and 30-

97 days post amputation. A homogenous cell suspension was made by grinding these tissues using 98 a homogenizer and 200 ul chloroform was added and shaken vigorously for 15 seconds. After 99 incubation for 10 minutes at room temperature for phase separation, the mix was centrifuged at $10010,000 \mathrm{~g}, 15$ minute, $4^{\circ} \mathrm{C}$. The upper aqueous layer was separated and an equal volume of 101 Isopropanol was added, incubated for 5 minutes, centrifuged at $10,000 \mathrm{~g}$ for 10 minutes. The 102 resulting pellet was washed thrice with $70 \%$ ethanol at $10,000 \mathrm{~g}$ for 5 minutes each. The air-dried 
103 pellet was dissolved in 50ul nuclease free water. RNA (1ug) was used to make cDNA using

104 Transcriptor High Fidelity cDNA Synthesis Kit (Roche \#5081955001) and primers (FP, ATA TGG

105 TAC CGT CTG CTC CCA GGG TTA G; RP, ATA TGC GGC CGC CTT GTG TCG AGT GTA TTC

106 AAT TGC) designed to amplify full-length transcript.

PCR cloning and Sanger sequencing: Gel extracted PCR product was cloned using TOPO ${ }^{\mathrm{TM}}$ TA Cloning ${ }^{\text {TM }}$ Kit (Invitrogen \#450640) as manufacturer's protocol. Sanger sequencing was performed to confirm the sequence of the clone. In vitro transcription to synthesize the probe was performed using DIG RNA Labeling Kit (SP6/T7 \#11175025910) with SP6 or T7 polymerase after

112 linearizing the plasmid by using restriction enzymes. The probes were purified by using 113 NucAway ${ }^{\mathrm{TM}}$ Spin Columns (\#AM10070).

RT PCR: Total RNA from tissue samples was used for cDNA synthesis (as above) primed by oligodT primer. Gene specific primers listed in supplementary information were used in quantitative RT-PCR reactions containing SYBR green master mix (Takara \#RR820). The Ct values were used to calculate Fold Change against spike-in control IncRNA (see results for details) using the method described by Michael W. Pfaffl (Pfaffl, 2001).

In situ hybridization: Regenerated earthworms were collected at 10, 15, 20- and 30-days post amputation (dpa) and washed thoroughly in running tap water followed by autoclaved milli-Q water. Earthworms were fixed overnight at $4^{\circ} \mathrm{C}$ in $4 \%(\mathrm{w} / \mathrm{v})$ paraformaldehyde (PFA) prepared in 1x PBS. After fixation, they were washed stringently in PBST (0.1\% Tween 20 in PBS) with subsequent storage in $100 \%$ methanol at $4^{\circ} \mathrm{C}$. Prior to hybridization, the stored earthworms were rehydrated with gradient of $90 \%, 75 \%, 50 \%, 25 \%$ and $0 \%(\mathrm{v} / \mathrm{v})$ methanol in PBST for $45-60 \mathrm{~min}$ each. Earthworms were permeabilized by $20 \mathrm{ug} / \mathrm{ml}$ Proteinase $\mathrm{K}$ for 45 minutes at $55^{\circ} \mathrm{C}$. Fixed them again in 4\% PFA for 20 minutes, blocked using hybridization buffer (50\% formamide, $1.3 x$ SSC, $5 \mathrm{mM}$ EDTA, $5 \%$ Dextran sulphate, $0.2 \%$ Tween $20,100 \mathrm{ug} / \mathrm{ml}$ heparin $\& 50 \mathrm{ug} / \mathrm{ml}$ yeast tRNA in DEPC treated water) for 60 minutes at $65^{\circ} \mathrm{C}$. Hybridization was performed using sense and antisense probes prepared in hybridization buffer overnight at $65^{\circ} \mathrm{C}$ in water bath. Stringent washes were performed at $65^{\circ} \mathrm{C}$ with hybridization buffer thrice for 30 minutes each followed by washes in TBST $(0.1 \%$ Tween 20 in TBS) for 15 minutes at room temperature. After incubation

134 at room temperature for 4 hours in 1:2000 dilution of anti-digoxigenin antibody (Roche 135 \#11376623) prepared in TBST containing 10\% FBS, TBST washes of 15 minute each at room 136 temperature were performed thrice and subsequently the tissue was stained using NBT (working 
concentration 500ug/ml; Roche \#11383213001) and BCIP (working concentration 562.5ug/ml, Roche \#11383221001) in developing solution $\left(0.1 \mathrm{M} \mathrm{NaCl}, 0.1 \mathrm{M}\right.$ Tris. $\mathrm{HCl} \mathrm{pH} 9.5,0.05 \mathrm{M} \mathrm{MgCl}_{2}$, $0.1 \%$ Tween 20 in DEPC treated water). Images were captured by mounting earthworms in $2.5 \%$ methylcellulose at $3.2 x$ and $5 x$ magnification.

\section{Results}

143 On the basis of transcriptomics analysis in the regenerating earthworm, we prioritized sixteen 144 potentially non-coding RNAs for further validation, since they were about $1 \mathrm{~kb}$ or larger and free

145 of low complexity repeats. We designed qRT-PCR assays to detect four of the predicted IncRNA 146 using the assembled transcript sequences (see methods; Supplementary data 1). Although 147 GAPDH is widely used as a control in gene expression studies, it was not suitable for 148 normalization in our experiments because it is strongly upregulated during regeneration. Instead, 149 we used a spike-in normalization method, by adding an in vitro transcribed RNA fragment to the 150 qRT-PCR reaction. The spike-in control IncRNA was originally cloned from the zebrafish genome 151 that has no sequence homology with the earthworm genome (Sarangdhar et al., 2017). We also 152 verified that the primers for this fragment produce no product when provided with the earthworm 153 cDNA as a template. In close agreement with the RNAseq data, all four IncRNAs were strongly 154 over-expressed in the regenerating tissue (Figure 1). As shown in the figure, the newly 155 regenerated segments expressed the IncRNAs at 4 to 8 times the levels in the adjacent control 156 segments.

Next, we cloned each IncRNA gene into the TOPO TA cloning vector and generated digoxigenin labelled probes by incorporating digoxigenin linked rUTP in the in vitro transcription reaction. These probes were used in in situ hybridizations in the collected sample containing regenerating tissue closely juxtaposed with the tissue from the worm before injury. Although there was a detectable signal in the regenerating tissue, the expression of the IncRNAs did not, in general, 163 have a distinctive spatial pattern (Supplementary figure2). A notable exception was the IncRNA of 895nt length that showed a recurring pattern of expression with four spots in each segment on 165 the ventro-lateral and ventral side in the regenerating region (Figure 2). Estimating from the $\mathrm{Ct}$ 166 values, the IncRNA was expressed at about one-tenth the abundance of GAPDH, making it quite 167 abundant, since IncRNAs are usually expressed at low levels. Since this abundant IncRNA was 168 restricted to tiny spots, the expression was strong and clearly visible. 
170 To understand the source of the signal (Figure 3A), we made longitudinal incisions on the dorsal

171 region and spread out the inner body wall. By gently teasing out the tissue around the signal, it

172 was clear that the spots were at the base of newly assembled chaetae (Figure 3B-C). Notably,

173 no such spots were seen at the base of the chaetae before regeneration (Figure $3 \mathrm{~A}$ ). Clearly, this

174 IncRNA was strongly but transiently induced in a very small group of cells closely associated with

175 the chitinous setae. Due to this interesting expression pattern, we named the IncRNA Neev, which

176 means base or foundation in Hindi.

178 In transcriptomics experiments, fragments of protein-coding mRNAs are sometimes erroneously 179 annotated as non-coding transcripts. Some legitimate IncRNAs may also produce functional 180 peptides from microORFs. To rule out spurious annotation and detect conserved microORFs, we 181 aligned the sequence of the Neev IncRNA to genome scaffolds assembled previously. Although 182 there was a 85aa open reading frame, it did not show any similarity to known proteins (Figure 4). 183 In the scaffold from which the Neev gene was derived, we found a neighbouring conserved region 184 of $232 \mathrm{nt}$ with strong similarity to many genomes including vertebrate model systems like zebrafish 185 (Figure 4; bottom right panel). By aligning the transcript sequence to the genomic sequence, we 186 found that the Neev gene comprises two exons and a 191nt long intron (Figure 4; bottom left 187 panel). Taken together, Neev codes for an IncRNA that satisfies all the currently prevalent criteria, 188 i.e. multi-exon, polyadenylated transcript longer than 200nt and is devoid of ORFs larger than 189 300nt (Clamp et al., 2007; Dinger et al., 2008; Frith et al., 2006; Niazi and Valadkhan, 2012).

Next, we tried to assign a potential function to the transcript. Since IncRNAs often regulate overlapping genes or genes in close proximity by RNA-DNA hybridization and recruitment of 193 chromatin modifiers, we first checked for relevant ORFs in the 5kb contig containing the Neev 194 gene. Since there were no genes in this region, we speculated that the IncRNA might regulate 195 expression of distant genes through RNA-RNA binding. Chaetae, i.e. chitinous setae originate in 196 bulbous cells called chaetoblasts, which put out microvilli that are subsequently coated with large 197 amount of chitin, presumably produced within these cells (Schweigkofler et al., 1998). We 198 reasoned that the chaetoblasts would also need to express chitin synthase genes transiently and 199 in a highly regulated manner. We checked our transcriptomics data for the expression pattern of 200 chitin synthase genes and chitinases. Amongst 29 genes with the word chitin in their name, 10 201 changed in expression during regeneration. We retrieved the basal expression level of these 202 genes and in agreement with our prediction, one of the chitin synthases, Chitin Synthase 8 
203 (Q4P9K9), showed a strong induction of 11 to 23 -fold in the regenerating tissue, compared to the 204 adjacent control tissue (Figure 5).

205

Next, we looked for potential RNA-RNA interactions that implicate the IncRNA in chitin synthase

207 regulation. We aligned the sequences of IncRNA with differentially expressed chitin synthases. If

208 they show similarity in anti-sense orientation, it could potentially form IncRNA-mRNA duplexes

209 that are usually targeted for degradation. More complex regulatory mechanisms like guidance of

210 splicing or RNA-RNA scaffold formation are also possible. In anti-sense orientation, the mRNA of

211 Chitin Synthase 8 could potentially bind to the IncRNA only at four stretches of 7 nt each.

213 We also looked for potential miRNA sponge like activity in the IncRNA sequence, because 214 sequestration of miRNAs may transiently de-repress chitin synthesis genes to facilitate 215 regeneration of chaetae. Since miRNAs tend to be highly conserved, we used the list of mouse 216 miRNAs to predict targets and later verified that the earthworm genome contained sequences 217 corresponding to the miRNAs of interest. We used the well-accepted miRNA target prediction 218 tool, miRanda (Betel et al., 2010) to identify the most frequently occurring miRNA targets in Neev 219 (Table 2). Two miRNAs were discarded from further analysis because we could not find the 220 corresponding region in the earthworm genome. Four miRNAs, each with more than 5 target sites 221 in the Neev IncRNA (see supplementary data2; Figure 4A) collectively had 49 sites of delG<-20C 222 in the Neev IncRNA of 895nt length. Next, we checked the Chitin Synthase 8 mRNA sequence 223 (length $=6202 n t$ ) to check for binding sites against the miRNAs. The four selected microRNAs 224 had $>100$ sites on average and collectively had 478 potential binding sites (delG<-20C). To check 225 for the rate of false positive predictions by the algorithm, we ran similar predictions for miRNA 226 binding sites in three endo-chitinase genes, but none of them showed a comparable enrichment 227 for binding sites of these miRNAs (Table 2). We also used 15 randomly selected $6 \mathrm{~kb}$ regions 228 (matching the length of Chs8 mRNA) from the earthworm genome, to ensure that the high number 229 of targets was not a consequence of the length of the Chitin Synthase mRNA. By comparing the 230 number of sites predicted in the randomly selected controls, we conclude that binding sites for 231 the miR-667-5p and miR-7658-5p are over-represented in the Chitin Synthase 8 mRNA and the 232 Neev IncRNA at a frequency significantly higher than expected by chance $(p V a \mid<0.001)$.

\section{Discussion}

235 Long non-coding RNAs are a large group of transcripts that are more than 200 nucleotides in 236 length, with no or some peptide coding potential with no well accepted criteria (Fang and 
237 Fullwood, 2016). LncRNAs are known to fold back into complex structures and mediate diverse

238 functions in cells ranging from recruiting chromatin modifiers to guiding alternative splicing and 239 sequestering microRNAs and proteins (Fernandes et al., 2019). We have previously identified 240 several non-coding RNAs that were highly induced in the regenerating region of the earthworm 241 from RNAseq data (Bhambri et al., 2018). The transcriptomics data was used in de novo assembly 242 of transcript sequences, which were further classified as non-coding if they did not contain an 243 open reading frame of more than 300 nucleotides in length. In agreement with the RNAseq study, 244 the qRT-PCR validation also showed that the IncRNAs were induced in the regenerating region 245 of the earthworm. The level of induction increased with time, till about 20 days post amputation 246 but then tapered off. This coincides with the timeframe when the regenerated segments acquire 247 almost all the features of the original segments and the transcriptional profile is largely restored 248 to the normal pattern.

To the best of our knowledge, this IncRNA has no ability to encode a protein. While many dubious IncRNAs are now thought to be spurious products of abortive transcription (Consortium and The FANTOM Consortium, 2005; Ebisuya et al., 2008; Struhl, 2007) the presence of two exons in Neev suggests that it is more reliable (Derrien et al., 2012). It is polyadenylated, and only expressed from one strand i.e. it does not overlap with a protein coding gene. Neither could we find any ORF in close proximity within the $5 \mathrm{~kb}$ contig containing the gene for Neev. Translating the 895nt transcript in all potential reading frames did not reveal any peptide with even minimal homology to a known gene. Unlike the typical IncRNA, Neev is expressed at high levels, only about 1/10th of the abundant GAPDH mRNA. Comparing the expression levels from the RNAseq data, it appears that Neev is more abundant than the chitin synthase 8 gene. Taken together, the reliable expression, poor conservation and presence of multiple exons agrees with it being a functional non-coding RNA.

Non-coding RNAs are found in large numbers in every genome, frequently outnumbering their protein coding counterparts (Derrien et al., 2012). The transient and localized expression of Neev 265 is in agreement with the view that they may be involved in establishing the fine spatio-temporal 266 regulation of genes in the regenerating tissue. LncRNAs are known to regulate gene expression 267 at various levels: by recruiting chromatin modifiers (Campos and Reinberg, 2009; Kanhere et al., 268 2010), directing splicing (Bernard et al., 2010; Tripathi et al., 2010), modifying stability of mRNAs 269 by masking motifs within the mRNAs (Kung et al., 2013; Matsui et al., 2008) or sequestering 270 miRNAs (Faghihi et al., 2010; Franco-Zorrilla et al., 2007). Some of these mechanisms inherently 
271 involve RNA-protein complexes, which cannot be predicted on the basis of RNA sequence.

272 However, some of the mechanisms can be predicted from the sequence of mRNA and IncRNA.

273 The direct binding of IncRNA and mRNA can be deciphered from stretches of apparent

274 complementarity while similarity at miRNA binding sites indicate the possibility of miRNA sponge

275 mechanism. On the basis of high frequency of binding sites for miR-667-5p and miR-7658-5p in

276 the mRNA of Chitin synthase 8 mRNA and Neev IncRNA, we speculate that the transient induction

277 of the IncRNA in a few cells at the location of the chaetae, temporarily releases chitin synthase

$278 \mathrm{mRNA}$ from repression, and facilitates the development of chaetae in the regenerating segments

279 (Figure 6). Further experiments are needed to test the predicted miRNA sponge like activity of 280 the IncRNA in vivo.

282 The position of the regenerating chaetae and the pattern of Neev expression can help in inferring 283 an invisible developmental boundary within the regenerating tissue. Immediately following the 284 injury, a mass of undifferentiated tissue, called blastema caps the site of injury. Within days, the 285 mass of cells starts differentiating to structures found within each segment even as rapidly dividing cells increase the volume of tissue. It was not clear if the temporal period of growth and cell division is completed before differentiation ensues. It is clear from our data that both differentiation and cell proliferation happen simultaneously. Further, it is also clear that the rapidly dividing cells are concentrated at the posterior tip while the differentiation zone abuts the site of injury. This is broadly in agreement with a recent report of zones within the posterior regenerating region of another annelid, Platynereis dumerilii (Gazave et al., 2013). Cells that exhaust their division potential are pushed down into the zone of differentiation where presumably local signals precisely position the chaetoblasts, which then adopt a transcriptional program distinctive from the neighbouring cells. At the site of injury, the newly formed segment has chaetoblasts expressing the Neev IncRNA, even as the pre-existing chaetoblasts (in the adjacent segment on the other side of the site of injury) remains immune to these local signals. The precise arrangement of the chaetoblasts in rows within each segment and columns that run across segments implies a very precise and local regulatory module that determines the expression of the Neev IncRNA.

\section{Acknowledgements:}

302 The authors acknowledge the support in genome analysis by Aksheev Bhambri. Technical 303 support by Jayashree Niharika and Pooja Bharali who repeated the in-situ hybridizations reported 
304 here is gratefully acknowledged. Although the figures generated by them were not used, their

305 independent validation of the data was useful in establishing the reliability of the data.

306

307 Competing interests: 'No competing interests declared'

308

309 Funding: SSP is supported through a Senior Research Fellowship from University Grants

310 Commission. 'This research received no specific grant from any funding agency in the public, 311 commercial or not-for-profit sectors.

312

313 
Bely, A. E. (2014). Early events in annelid regeneration: a cellular perspective. Integr. Comp. Biol. 54, 688-699.

Bernard, D., Prasanth, K. V., Tripathi, V., Colasse, S., Nakamura, T., Xuan, Z., Zhang, M. RNA regulates synaptogenesis by modulating gene expression. EMBO J. 29, 3082-3093.

Betel, D., Koppal, A., Agius, P., Sander, C. and Leslie, C. (2010). Comprehensive modeling of microRNA targets predicts functional non-conserved and non-canonical sites. Genome Biol. 11, R90.

Bhambri, A., Dhaunta, N., Patel, S. S., Hardikar, M., Bhatt, A., Srikakulam, N., Shridhar, S., Vellarikkal, S., Pandey, R., Jayarajan, R., et al. (2018). Large scale changes in the transcriptome of Eisenia fetida during regeneration. PLoS One 13, e0204234.

Campos, E. I. and Reinberg, D. (2009). Histones: annotating chromatin. Annu. Rev. Genet. 43, 559-599.

Clamp, M., Fry, B., Kamal, M., Xie, X., Cuff, J., Lin, M. F., Kellis, M., Lindblad-Toh, K. and Lander, E. S. (2007). Distinguishing protein-coding and noncoding genes in the human genome. Proc. Natl. Acad. Sci. U. S. A. 104, 19428-19433.

Consortium, T. F. and The FANTOM Consortium (2005). The Transcriptional Landscape of the Mammalian Genome. Science 309, 1559-1563.

Derrien, T., Johnson, R., Bussotti, G., Tanzer, A., Djebali, S., Tilgner, H., Guernec, G., Martin, D., Merkel, A., Knowles, D. G., et al. (2012). The GENCODE v7 catalog of human long noncoding RNAs: analysis of their gene structure, evolution, and expression. Genome Res. 22, 1775-1789.

Dinger, M. E., Pang, K. C., Mercer, T. R. and Mattick, J. S. (2008). Differentiating proteincoding and noncoding RNA: challenges and ambiguities. PLoS Comput. Biol. 4, e1000176.

Ebisuya, M., Yamamoto, T., Nakajima, M. and Nishida, E. (2008). Ripples from neighbouring transcription. Nat. Cell Biol. 10, 1106-1113.

Faghihi, M. A., Zhang, M., Huang, J., Modarresi, F., Van der Brug, M. P., Nalls, M. A., Cookson, M. R., St-Laurent, G., 3rd and Wahlestedt, C. (2010). Evidence for natural antisense transcript-mediated inhibition of microRNA function. Genome Biol. 11, R56.

Fang, Y. and Fullwood, M. J. (2016). Roles, Functions, and Mechanisms of Long Non-coding RNAs in Cancer. Genomics, Proteomics \& Bioinformatics 14, 42-54.

Fernandes, J., Acuña, S., Aoki, J., Floeter-Winter, L. and Muxel, S. (2019). Long NonCoding RNAs in the Regulation of Gene Expression: Physiology and Disease. Non-Coding RNA 5, 17.

Franco-Zorrilla, J. M., Valli, A., Todesco, M., Mateos, I., Puga, M. I., Rubio-Somoza, I., Leyva, A., Weigel, D., García, J. A. and Paz-Ares, J. (2007). Target mimicry provides a new mechanism for regulation of microRNA activity. Nat. Genet. 39, 1033-1037. 
352

353

354

355

356

357

358

359

360

361

362

363

364

365

366

367

368

369

370

371

372

373

374

375

376

377

378

379

380

381

382

383

384

385

386

387

388

389

390

Frith, M. C., Bailey, T. L., Kasukawa, T., Mignone, F., Kummerfeld, S. K., Madera, M., Sunkara, S., Furuno, M., Bult, C. J., Quackenbush, J., et al. (2006). Discrimination of non-protein-coding transcripts from protein-coding mRNA. RNA Biol. 3, 40-48.

Gazave, E., Béhague, J., Laplane, L., Guillou, A., Préau, L., Demilly, A., Balavoine, G. and Vervoort, M. (2013). Posterior elongation in the annelid Platynereis dumerilii involves stem cells molecularly related to primordial germ cells. Dev. Biol. 382, 246-267.

Hausen, H. (2005). Chaetae and chaetogenesis in polychaetes (Annelida). Hydrobiologia 535536, 37-52.

Kanhere, A., Viiri, K., Araújo, C. C., Rasaiyaah, J., Bouwman, R. D., Whyte, W. A., Pereira, C. F., Brookes, E., Walker, K., Bell, G. W., et al. (2010). Short RNAs are transcribed from repressed polycomb target genes and interact with polycomb repressive complex-2. Mol. Cell 38, 675-688.

Kung, J. T. Y., Colognori, D. and Lee, J. T. (2013). Long noncoding RNAs: past, present, and future. Genetics 193, 651-669.

Matsui, K., Nishizawa, M., Ozaki, T., Kimura, T., Hashimoto, I., Yamada, M., Kaibori, M., Kamiyama, Y., Ito, S. and Okumura, T. (2008). Natural antisense transcript stabilizes inducible nitric oxide synthase messenger RNA in rat hepatocytes. Hepatology 47, 686697.

Niazi, F. and Valadkhan, S. (2012). Computational analysis of functional long noncoding RNAs reveals lack of peptide-coding capacity and parallels with 3' UTRs. RNA 18, 825-843.

Pfaffl, M. W. (2001). A new mathematical model for relative quantification in real-time RT-PCR. Nucleic Acids Res. 29, e45.

Planques, A., Malem, J., Parapar, J., Vervoort, M. and Gazave, E. Morphological, cellular and molecular characterization of posterior regeneration in the marine annelid Platynereis dumerilii.

Sarangdhar, M. A., Chaubey, D., Bhatt, A., Monisha, K. M., Kumar, M., Ranjan, S. and Pillai, B. (2017). A Novel Long Non-coding RNA, durga Modulates Dendrite Density and Expression of kalirin in Zebrafish. Frontiers in Molecular Neuroscience 10,.

Schweigkofler, M., Bartolomaeus, T. and von Salvini-Plawen, L. (1998). Ultrastructure and formation of hooded hooks in Capitella capitata (Annelida, Capitellida). Zoomorphology 118, 117-128.

Struhl, K. (2007). Transcriptional noise and the fidelity of initiation by RNA polymerase II. Nat. Struct. Mol. Biol. 14, 103-105.

Tripathi, V., Ellis, J. D., Shen, Z., Song, D. Y., Pan, Q., Watt, A. T., Freier, S. M., Bennett, C. F., Sharma, A., Bubulya, P. A., et al. (2010). The nuclear-retained noncoding RNA MALAT1 regulates alternative splicing by modulating SR splicing factor phosphorylation. Mol. Cell 39, 925-938.

Xiao, N., Ge, F. and Edwards, C. A. (2011). The regeneration capacity of an earthworm, Eisenia fetida, in relation to the site of amputation along the body. Acta Ecologica Sinica 
31, 197-204.

\section{Figure Legends}

395 Figure 1: Validation of novel IncRNA upregulated during regeneration by qRT PCR. Eisenia fetida worms were amputated at approximately the 60th segment from the anterior end and allowed to regenerate over a period of 30 days. At 15, 20- and 30-days post amputation, the regenerating tissue $(15 \mathrm{R}, 20 \mathrm{R}, 30 \mathrm{R})$ and adjacent control tissue (15C, 20C, 30C) were collected. RNA isolated from these tissues were used for qRT-PCR (see methods for details; primer sequence). The IncRNAs, being novel were named according to the size of the transcript assembled from RNAseq data. (Biological replicates $(N)=3$; technical replicates $(n)=3$; t-test, * $p$ val<0.05; $\left.{ }^{* *} \mathrm{p}-\mathrm{val}<0.01\right)$

Figure 2: IncRNA Neev expression pattern in Eisenia fetida regenerating tissue. Earthworms were allowed to regenerate for 10, 15- and 20-days post amputation (dpa). Whole mount in situ hybridization of the regenerating tissue was performed using probe RNA synthesised by in vitro 407 transcription. The antisense probe (right) showed distinct expression signal on the ventral side 408 (arrowhead), while the sense probe (left) served as negative control ( $n=5$; typical results are 409 shown here). Asterisks marks are placed over air bubbles (Scale bar=100micrometre)

411 Figure 3: The IncRNA, Neev, is expressed at the root of chaetae in the regenerating tissue. After 412 15days post amputation (15dpa) whole mount in situ hybridization was performed on the 413 regenerating worm (see Figure 2 and top panel; scale bar: 100micrometre). The tissue was 414 dissected from the dorsal side to expose the root of the chaetae and imaged at 10X magnification 415 (B) and $40 \mathrm{X}$ to visualize the expression of the IncRNA.

417 Figure 4: Alignment of IncRNA Neev with Eisenia fetida genomic scaffold SACV01159372.1. 418 Prediction of Open Reading Frames (ORFs) in the genomic contig showed 38 small ORFs with 419 no functional annotation (top panel). Neev IncRNA contains two exons (bottom left panel) and a $420191 \mathrm{nt}$ intron. Only one ORF about 900nt in the $3^{\prime}$ direction was conserved in other organisms 421 (bottom right panel).

423 Figure 5: IncRNA Neev expression coincides with several chitin metabolism genes. The pre424 amputated zone at 15, 20- and 30-days post amputation (15C, 20C and 30C) does not show any 
425 expression of these genes while four Chitin metabolism genes and Neev are strongly induced in 426 the regenerating region at corresponding timepoints (15R, 20R and 30R). The numbers depict $427 \log _{2}$ Fold Change with respect to similar region of pre-amputated worm.

428

429 Figure 6: Schematic Depiction of gene regulation in the chaetoblast during regeneration. In the 430 pre-amputation zone, Chitin Synthase 8 is repressed by miRNAs while in the differentiation zone, 431 expression of Neev leads to sequestration of miRNAs and derepression of Chitin synthase 8. The 432 posterior growth zone at the tip of the regenerating earthworm comprises undifferentiated cells. 433 
Figures

437

438

439

440

441

442

443

444

445

446

447

448

449

450

451

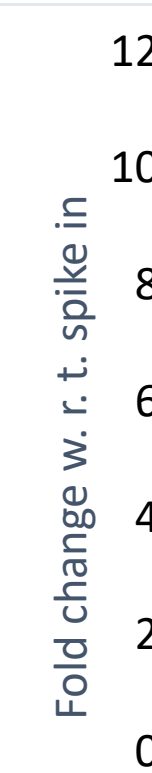

12

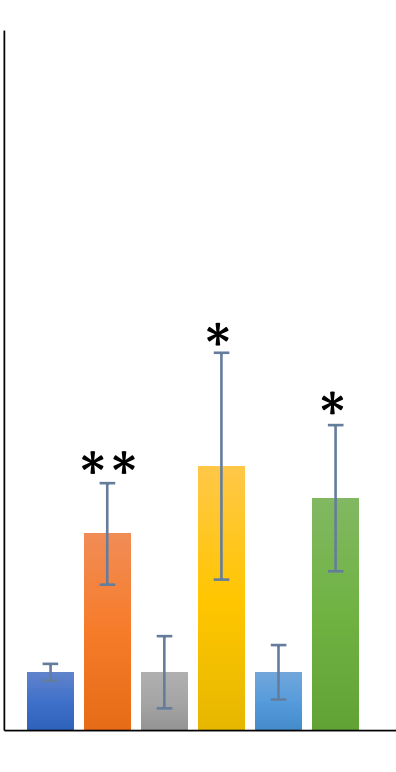

Inc895

Inc927

\section{InCRNA}

453

454

456 Figure 1

457

458

459

460

461

462

463

464 
bioRxiv preprint doi: https://doi.org/10.1101/806661; this version posted October 16,2019 . The copyright holder for this preprint (which was not certified by peer review) is the author/funder, who has granted bioRxiv a license to display the preprint in perpetuity. It is made available under aCC-BY-ND 4.0 International license.

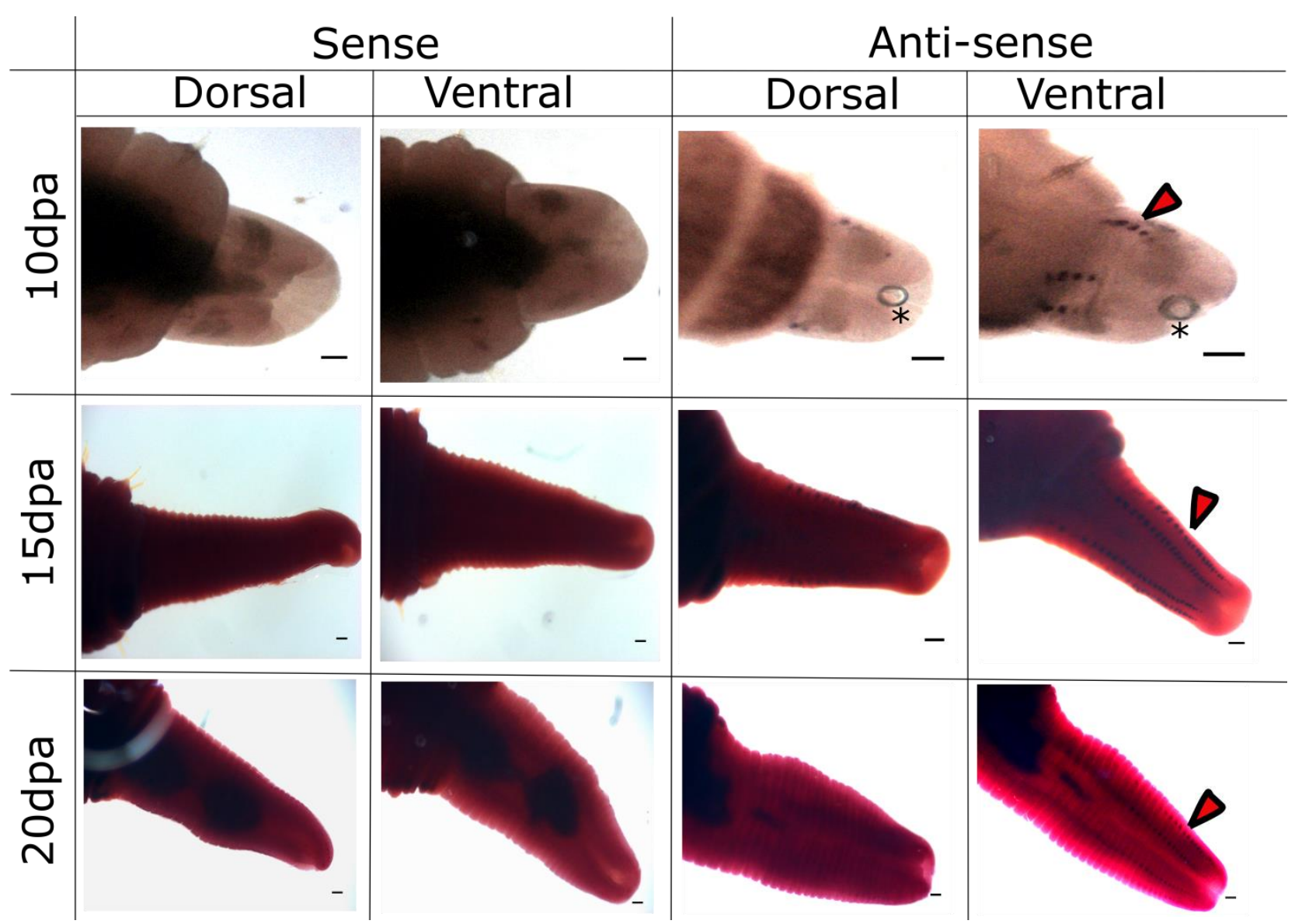


bioRxiv preprint doi: https://doi.org/10.1101/806661; this version posted October 16,2019 . The copyright holder for this preprint (which was not certified by peer review) is the author/funder, who has granted bioRxiv a license to display the preprint in perpetuity. It is made available under aCC-BY-ND 4.0 International license.

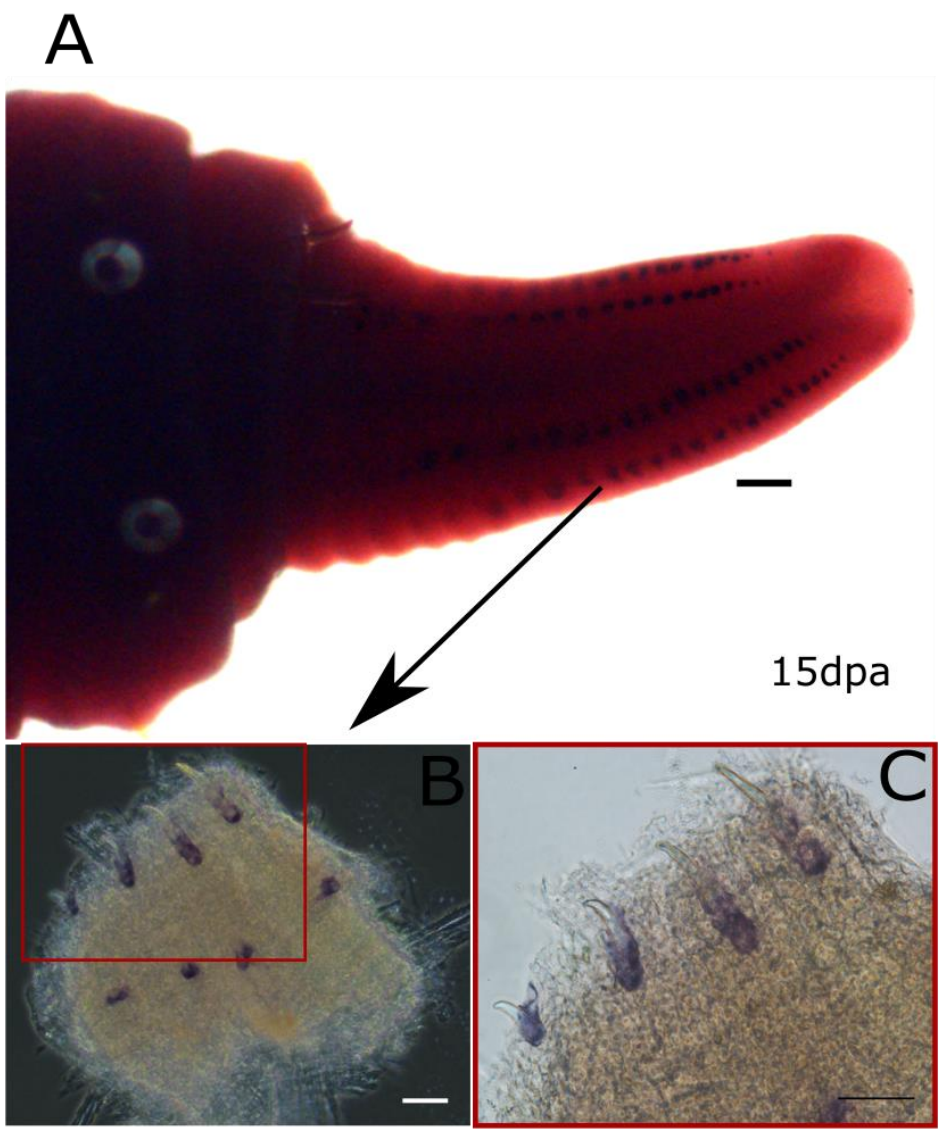

489 Figure 3: 
bioRxiv preprint doi: https://doi.org/10.1101/806661; this version posted October 16,2019 . The copyright holder for this preprint (which was not certified by peer review) is the author/funder, who has granted bioRxiv a license to display the preprint in perpetuity. It is made available under aCC-BY-ND 4.0 International license.

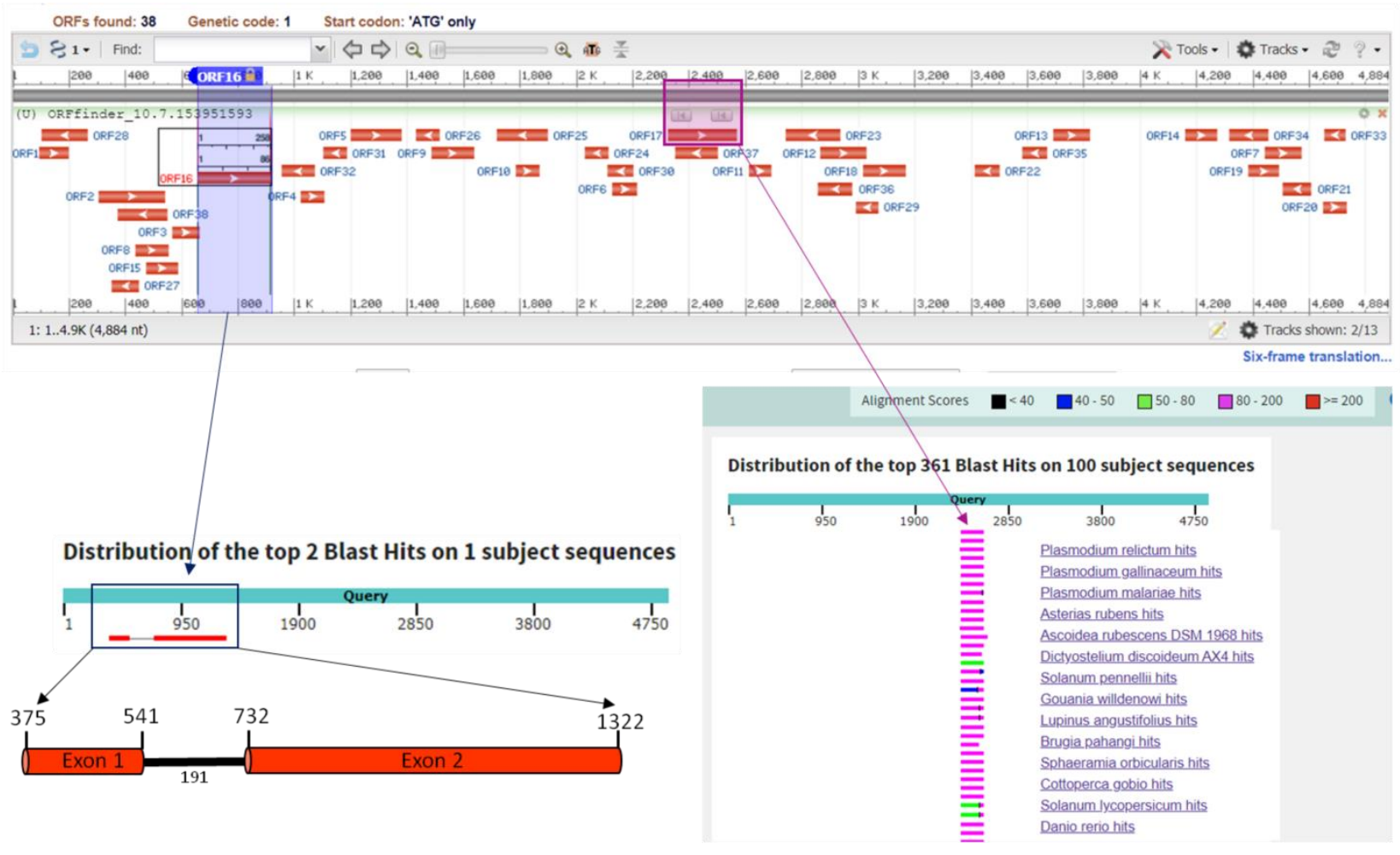


bioRxiv preprint doi: https://doi.org/10.1101/806661; this version posted October 16,2019 . The copyright holder for this preprint (which was not certified by peer review) is the author/funder, who has granted bioRxiv a license to display the preprint in perpetuity. It is made available under aCC-BY-ND 4.0 International license.

505

506

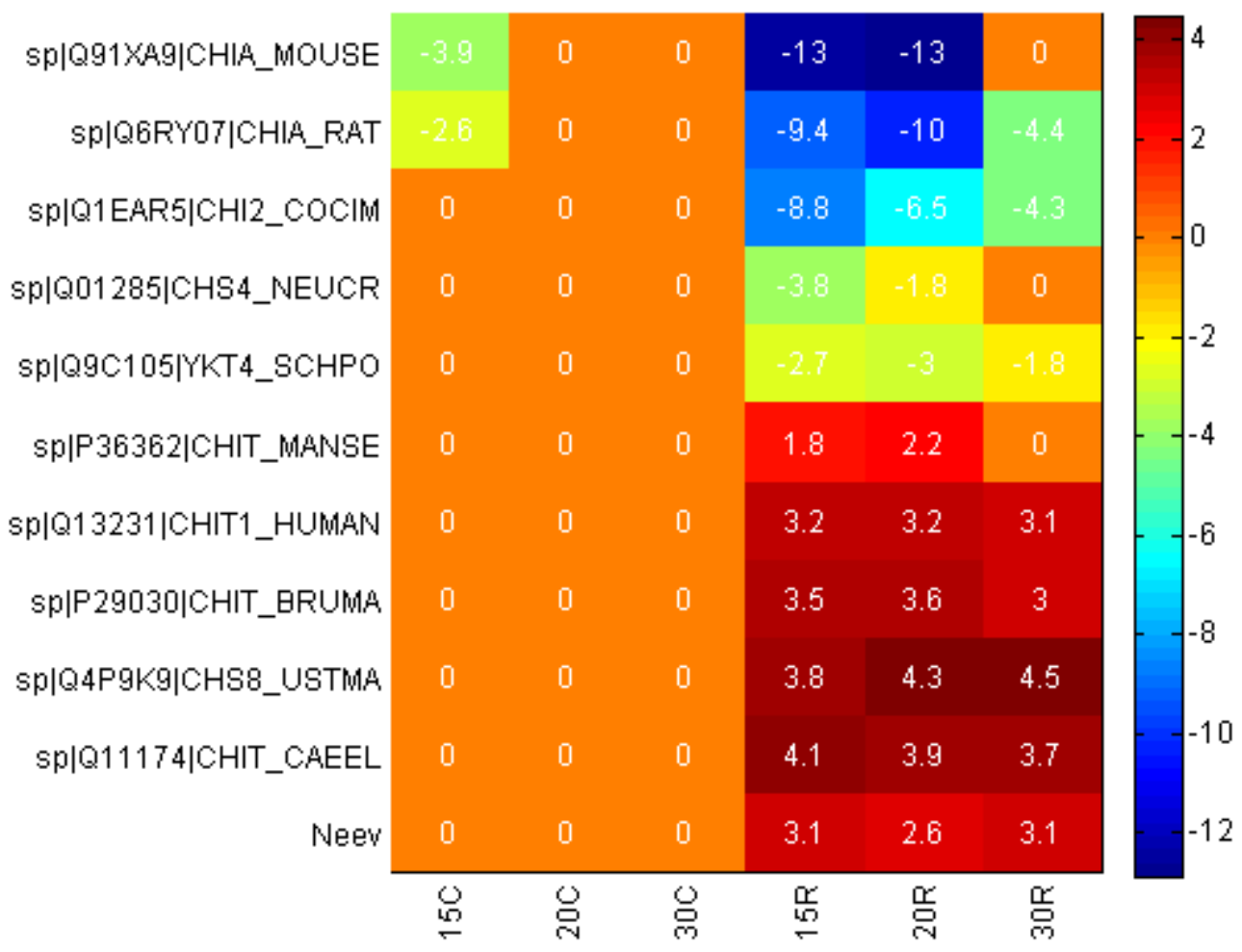

507 Figure 5:

508 
bioRxiv preprint doi: https://doi.org/10.1101/806661; this version posted October 16,2019 . The copyright holder for this preprint (which was not certified by peer review) is the author/funder, who has granted bioRxiv a license to display the preprint in perpetuity. It is made available under aCC-BY-ND 4.0 International license.

509

510

Pre-amputation Zone

Differentiation zone

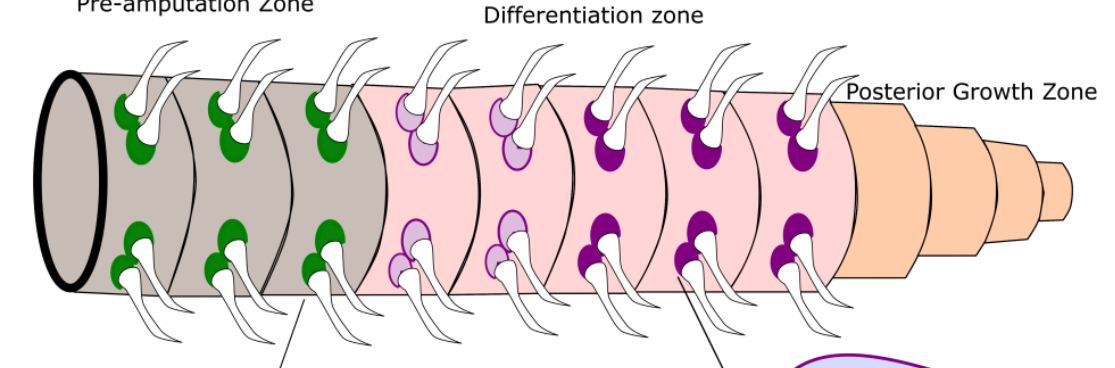

511

512

513 Figure 6:

514

515 
bioRxiv preprint doi: https://doi.org/10.1101/806661; this version posted October 16,2019 . The copyright holder for this preprint (which was not certified by peer review) is the author/funder, who has granted bioRxiv a license to display the preprint in perpetuity. It is made available under aCC-BY-ND 4.0 International license.

516

517 Supplementary information:

518

519 Primers used for qRT PCR

520 Neev (Inc895) FP: GGTTCCAGAGCCGTAATGTTC

521 Neev (lnc895) RP: GCTACCATCATCGTCTTGCTG

522 InC927 FP: TGAATGCTCGCTCTCCTACAT

523 Inc927 RP: TGGAATATTGCTGGAAAATGG

524 Inc1040 FP: ACCCAAAATGCACTGAACCAA

525 Inc1040 RP: TTTGCTCCGTCTTTTCGTCTG

526 Inc1583 FP: GAGCCAACTTGAACCAACTGT

527 Inc1583 RP: AATGCAACACTACCGACAACC

528 Spike-in qRT FP: CCTCTTGTATCTCACAGCTCAA

529 Spike-in qRT RP: CTGGAGACAATAGAAGGCAAT

530

531 
bioRxiv preprint doi: https://doi.org/10.1101/806661; this version posted October 16,2019 . The copyright holder for this preprint (which was not certified by peer review) is the author/funder, who has granted bioRxiv a license to display the preprint in perpetuity. It is made available under aCC-BY-ND 4.0 International license.

\section{Supplementary data 1}

533

$534>$ Neev TRINITY_DN307027_c2_g1_i1

535 CTTGTGTCGAGTGTATTCAATTGCTTTACGTCGGCGTCAGTTTGGGAACACAAGTCACCA 536 TGAGAACCGCTACCATCATCGTCTTGCTGGTCGTTGCTTTTGCGGCCGTGACTTACGCCG 537 GATACTATCCAGGATATCATCGCACGCCCAATGGAATTGCTGCCGTTTACCGCAACGACC 538 TCCGACAGGTCCACGTGAACAATGTCGCTGAACATTACGGCTCTGGAACCGGAACAGCCA 539 GATGGAACGGAGTTCCAGGCACCGGACGCCACTTTGGATATGGATACCACCACGGATATG 540 GATATTAAGAAACGTCACGAATGCTGTATCCGAAATTGCGTCATTGCTCAACAAATTACA 541 CAATGAAGAGAATGTGTATAGAAACAGATTAAGCCACAAGTGCCAACGTTGCTTTCACTT 542 TGAGATTGACTTATTTATCGGCTCCTTGTCTCAGCTACATTCCAAAGACTCTAATCATTC 543 ATATTGATGCTAGAAAATCTGATACGATTGTTGAAAGTGATTTGTCTCATTGTAAATTAA 544 AAACAAGTTCCGTTGTTGTATAAAATAAACAAGATCGCACGCTCACAGGAAATTCCATGT 545 TCCACGATTGCCGAAAACAGTGTAATACTCCATATATGGTCATTTCTTTTTCATTACGAG 546 TTGTCCGTAAACGATGTTAGTAAAAAAGTACGTACTTTTCAACCCTGTCCGCTTTTGGGC 547 TTAGTCCTCTTTCCCCTTTGTGGACATCCGCATCTAGCATCAGACACTGCTCAATGGTCT 548 GGCAGTCTGGTGCTGTCAAAATACGCTGCTCATTGATCTCATTACAACATGCAACTCACA 549 ATAAAGACAAAATCAACAGAGACTTAATTAAACAACCTAACCCTGGGAGCCAGAC $>$ Chitin Synthase 8 TRINITY_DN356441_c0_g2_i2 CAAACAATGAACGGGTCTGGTCAGTCTGACCATCGCATTCGCACGGTCAACGTCAGGTGA GAGAGAGAGCAAGTGACCGAACATCGGCTACATTCGTTCACTATCAACATTCCGTTACAA TCTCTCCGGATAAACATCGGAGCCTCGATTTAACTAACGTCTGGAGTCGAATGTTCTTCA ACGCTGGAAAGTATTCCGGGGCAGGATAGAAATCGGAGTCTACGCTTTGGTTCTCCAGTC GAGGCTCAGGAAACGGTTCATCTTTCTCGATGATGATTATTTAAACGGCTGAAGCAGGAT TTTGTTGCGGTTTCTGTCGCTCGAAATTCAGGGCATTCGTCTTACAAGTCCTTCTCTGCC TCTTGTTAAGCACGATTTTAATTCAGTCCTAAAGCTTTTCTTTTCGTAAGCTCCATCGTC TATGATGCAAGGTCCAATCGCTTGCGTCCTGATATGCTCGTTATCTGTTGTTCGGTAAAC TCTTTCTCTGATCTTTCCTAAGCCTAAGTGTCTGGTAAGCTCAATCTTTGGTGTTTCAAA GACAATCTGCAGACTGTAATGTCTTATTAGCCCAATAAATAATATTAGGTTCAATCAATT TCCAGCGATAAGCTTGGTCTTTCTCAGGGATCCGCCCGAAATTATCATATTTCTTATAGC TCCTCGAACTGTAGGCCCACTACCAGTCCTCGCTGGCCTTGTCAGTTTACCATCTTAGTT GATTAGTGAGTTCTCAGTACTTCTTCTTTGCTCCTTGTGTTTTAACATTTTTTTCCAGTT TAGCTTTTCATTCATTTCCTTTATCATTCCATCTGCTATCCACTGCTTCTTTGGTCTTAT CCCAACATCTATTTAGCTATCGGCTCATTTTTTATGCTGTTCAGCCATATCCCTTCATTG AAGGACTAGGCCTTGTCGATCTCTGGTGATAATCTCGTTTCCGCAGGCCTGATAAGTCCT AACTGCAGAGATAGATTCTGTGTCTAAAGCAAAGGCTTTTTGTCGAGTAGGCCTATACTT CCCCGCATTTTTGACAGTCTGAGTTTGAGTCGACGACCAGTTATAATAGTAAAAATAAAC AATAAACAGCATAGTCGTCCAATCAACTTATCGAACGTGTTCCGGTTGTATTCTGACAAC TTTTACCGCGATACATAACACAACGACAACGAGTAGGGCCTACAACGCTTGAAAGCTGCT GCCTGGTGCTTGTTGAAAAACGAAGCCAAGGCTTTGGTTTCTTTGTGGCTTCTTAGGAGA CTGTTCCTTTTTCCATAATTATTATGCTGAGAATCTAAATGACCTTTGCGGGATATCTTC AAAGATAGTGTTAATCTGGAGACACGACATTCAGTTCAAGGTGCTCAATAGAGAGCAAGC AGATCGAGGGTGTTAACGATGGGCACGATCAGAGGTCGGAAGCCAGGGAGAGACAAGACA GTCTTCATGACAGTGTCACGTGACAGTGGTGTCGTGGCGGCGCAGTGCTTTGAGGGACCT 
bioRxiv preprint doi: https://doi.org/10.1101/806661; this version posted October 16,2019 . The copyright holder for this preprint (which was not certified by peer review) is the author/funder, who has granted bioRxiv a license to display the preprint in perpetuity. It is made available under aCC-BY-ND 4.0 International license.

578 GTTCGCATAGTTAAGTGCGCTGTCTATCTCCTCTTCTTCGCGATCATCGTCGCATGCGCA 579 TTCGCCAGCAAGGTCAGCCTCGTCGTCATGACAACCGGAGCCGGTGACCAGACAAAGACG 580 AAgTTTGAACGTGACTTGATCATTGTAATGCTCGCCTTTTCCATCTGCGTTCCCAATGTC 581 TTCACGTTCTTCGAGAGCCTGATGAAATCCGTCTTCGGGAACAAGGCTTGGCCGACCTTT 582 GGAACCATCTTCGTGGTGTTCCTGACTGAGGCGGCGCATTCCTTCGGTCTCTGTCTCTTC 583 GTCTTTCGTGTTCTACCCCAGTATGACGTAATTCGTGCCCTCCTCCTCATGTGCTCCACG 584 AACATAGTACCCAGCATCCTCAAGCTGATTCTGACGAAGGGTGACCGGGGCCCCCTAGCC 585 GTCGTCATGGACATCCTCGCCGTTGCCATGCAGTCGTCGGTCTTCTTCCTCATGACGGTC 586 TTCGACCGGGGGGAGGGCACCCAGGGAGCGTCGGGGGGAGTCGTACCCCTCGTCGAGTTG 587 GCCGCCTCGCTGGTGCTTATATCTGTCCGCTACTGGGAGAACTTCATCGATAGGGACATC 588 GGAGCGATTCCACTGCTCGGCTTCAAGCAAACGATGAGGCTCGGCCGGTGCAAGACCTAC 589 ATCTTCGCCAGCCTCTGGAAGATGGCCCTGACCCTGGCCTTTGCCTACCTGCTCGTGCCC 590 CACATGACCCCGATGGCTGACCTCTTCGCCCATATCGGAAACGAGACGGCCTACGACAAC 591 CGCACCGTCAGAGCTGGCCCGGACGGACCGGACGAGTACCCGGCCCCAACGGAGCTTGTG 592 TACCCGGACCCGGGCAGCGTCGACTATTCGCCCTCCTCCTCCGACGGGGCCGATTATCCC 593 GTCGAAGTGCCCACCGAACCCGACCTCGTCACTGAGTCCCTGGGGGCCAGGGTCCGACGT 594 GAGATCATACCCCCGCCAGGGACCCAAGACCTCACGACAGAAACACCCTCCACCCCAGCT 595 ACCTCTCCGTCAGTCGCTACGAACCCCATCGACGACCACCCTACCAACGATAGAATACCC 596 CAGCGGAGACCAAAATTGACTTCCCGCGTCTACCCCTCTCACCACCCTCGCCTTCCGGAA 597 GAAGACATCCCGGCGGGGTACGACTACTACAACGATCCGGAAGGCGACGAAGATCTTACC 598 TCCGACCTCACGGACGATGAAGTCAACCGGGTTCTCTACCGACTCCTGCCCCTCATCGTT 599 CAAGCCGCTTCTGGCGCCATCTGCTACTACTTCTCCCGAGTCGCATGTAAGCTGTGCATG 600 CAGAGGTTCAGTTTCAGTCTACCGCTTACGATCATCACCCCTGGAACGTTGGCGATCTTC 601 TGCTACCTCTGTCACCTCGGAGAATGGACCGAGCTGCGCCTTCCGAACGTCGAGGTGGGG 602 TTCTGGAGGTGCTCGGAGTCGTACCAGCAGAGGGCGTTCCAGTGGCAGATCGGATGCGCC 603 GTCGGGCTCTGGTGGCTGTCGCAGCTCTGGATCAACAATCACATCTGGTTCCCGAAGAGC 604 GAGAGACTGGCCAAGGTCGAACGACTATTCGTCCTGCCTCAGTACTGCGGCAGTCTTCTG 605 GAACAATCTCTGATGCTGAACAGGCGTCGGAACGACCACGAGGAAAACGAGCAGAACTCG 606 ACGAAGGCGAGGTCGGACCCTGTGGTGGGTGGGGTCGATGATTCCGCCTCGATGGTCGGC 607 TCAGTCATATCCGAGGGGGAGAGAACGAGAATTCGCGAAGGGGTGCACACGAGGATTTAC 608 GTCTGCGCTACCATGTGGCACGAAACGGCCAACGAGATGGTCCAGGTGCTTAAATCCATC 609 ATGAGAATGGACGTTGACCAGTCGGCAAGGACAAACGCTCAGGAATACTTTGGCGTCAAG 610 GATCCGGATTACTACGAGTTCGAAGCTCACGTTTTCATCGATGACGGCATGGAGGCAAAA 611 GACAGTGACGTCATCTGCAATCGTTTCGTCAAACAACTCGTTGACGTTATCGAACTGGCA 612 GCCACGTCTATCCACGAGACGCAGCTGGTCTTAGCGCCACCCTATAAGATCCCAACTCCA 613 TACGGGGGTCGGCTGATGTGGACTCTACCCGGTGGTAACACCCTCTACGTCCACGTGAAA 614 GACAAAAACAAGATCCGACACAAGAAAAGATGGTCGCAGGTGATGTACATGTACTATCTC 615 CTTGGATACCGTCTCCTTGGTAGCAACGACGACTCCATGTACTCTAACCAATCAGATGTC 616 GGCAAGACGAATCGAGCGGAAACGAGTCTCCATGCCAACATCACGCAGCGCAGTAAAATC 617 TTCCGCAGCATGAACCACATCCAAAGGGTCCAGGCGGAGAACACTTACCTGTTGACCTTG 618 GACGGTGACATTGACTTCAAGGCCGAGTCTGTCACCCTGCTCGTTGACCGAATGAAGAAG 619 AACAAGAAGGTGGGGGCAGCCTGTGGCCGCATTCACCCGATCGGAACAGGTCCTATGGTC 620 TGGTACCAGAAGTTCGAATATGCCATCGGTCACTGGCTTCAAAAGGCGGCTGAGCACATG 621 CTCGGCTGCGTGCTCTGCAGCCCCGGATGTTTCTCTCTCTTCCGGGGATCCGCCATCATG 622 GATGACAACGTCATGCGCACCTACGCCACCAAATCAACCGAAGCCAGGCACTATGTCCAA 
bioRxiv preprint doi: https://doi.org/10.1101/806661; this version posted October 16,2019 . The copyright holder for this preprint (which was not certified by peer review) is the author/funder, who has granted bioRxiv a license to display the preprint in perpetuity. It is made available under aCC-BY-ND 4.0 International license.

623 TACGATCAAGGCGAAGATCGCTGGCTCTGCACCCTCCTGCTTCAGCAGGGCTACAAGGTG

624 GAGTACTGCGCGGCGGCCGACGCTTCCACCTACGCCCCGGAGACGTTCAAGGAGTTCTAC

625 AACCAACGCCGACGCTGGATACCATCGACCCTCGCCAACATGATGGATCTGATGTCCGAC

626 TACCACCGGACAGTCATGGTCAACGACAACATCTCCTACCTCTATATGATGTACCAGGCG

627 GTCGTCATGGGTGCCAGCCTCCTCGCCCCGGCCACCGTCATCCTGATGGTCGCGGGGGCC

628 ATTCACGTGGTCGTAGGGGGAAGTCTCTACTGGCTCTGGTTGGCCTTCTCGGTTGGGGCG

629 GCAGTCTTCTACATGCTCGTCTGCTTCAAGTGCACTGCAGAAACACAGGTGTCGGTTGCT

630 GGTTACATGAGCACAGCCTACGCCATCCTCATGTTGGCCGTGACGGTCGGCATCGTCGTT

631 CAGACTTCTCAGGACTCGTGGACGAGTCCAAACGCCATGTTCATCATCGTCATAACGGGC

632 ATCTTCATCCTGGCCGGACTGCTCCATCCGGAGGAGTTCATGTGCCTGATGCCGGGCGTC

633 СTCTACTTCCTCTGCATCCCGTCCGGATTTCTCCTCCTCTTTATCTACGCCATGATCAAC

634 ATGAACATCGTGTCGTGGGGTACGAGAGAGGTCAACCAGGCGGAGGACGTCGACCGTGCA

635 AAGGTCAAGGCGACGTCGGCCAGGGTCCGGTTCCTCCGAGAGGTCCGCCGCATCAGTCTG

636 ACGGTCTGCTGCTGCATCAAGGATCGTTGTGTGTCCTTCATCGAGAGGAAGAGCCGCCCG

637 CAGCAGCCGAAGAAGGACGAGATCGTCAAAGAGATCCTCTCCGAGCTCGGCAAGATCGAG

638 TCGGGCGGCCACGGGGTCGGAGGTCAGGGCCCGAGGTCATCCGGCCCGCTCGGGGTCGGA

639 GGTCAGAGCTCGAGGGCGCCCTCTAGTCAGGGCGGCGGTCTTGACATCGATCCAAGGTCC

640 GTCTACGAGGGGGCGTACGGCTACCCCGCTCGTCCGGCCTTGAACTTGCTCGAGGAGAGA

641 CAGCGAAGCATCGTCCGTCAGCTGGATAGCATCCAAGGTCAGGCGATGCAGGAGACCATC

642 AGCATTCCACAGGATTACAGTCACCTCGAGATCGAGGACTCGTCCACGACCGGGGTCAAG

643 GCGCAGACGCCCCACAAGGTCAAGGAACCCTCCCCGTCCTCATCATCATCAACCTCCTCC

644 TCTTCGTCGGTTGTGGGAAGGGTCAGTCCAAAGCCGGGGCACAGCTCCCCGCCACCGCCG

645 CGGGCAATCAGACGAGACGACCTATGGGTAACGGATCGAGACCTCGGCAGCGGACCAGTG

646 CGCCTCATGGACCCGAGCGAGACGCTGTTCTGGCGGAAGCTCATCGAGAAGTACCTTTAT

647 CCGATCGACCAGGACAGGACTCACGAGGCGAAGATCCGGAAGGACCTGAAGACGCTGAGG

648 AACAACGCCGTCTTCCTCTTCTTCATGCTCAACTTCCTCTGGCTCTTCATCATCTTCCTG

649 CTCCAGATCGTCCAGGACCAGCTCCAGGACACGCTCTACATCCGCGTCCCGAAGCGCGGC

650 GGCACTGACGAGAAGCACTTCGAGCCCCTCAGCGTCGCCTTCCTCGTCTTCTTCGCCCTC

651 ATCATCCTCATCCAGTTCGTGTCCATGCTCTTCCACCGCTACGGAACCTTCCTCCACATC

652 CTCGCGTCGACGGGTTTGCGCTGCTGCAGCAAGCAGTACGAACCCATCGCCATAGAGGAC

653 ATCGTCCAGACGGTAAAGGTCCTGCAGCAGATCAAAGGCATCATAGATGATGACGACGAC

654 GACGATGATAACGACGACGAGGATGATGATGATGCGGATCCGGACTACGACATGATGGGA

655 GAGCGAGGGGACCCGGACCACG 
bioRxiv preprint doi: https://doi.org/10.1101/806661; this version posted October 16,2019 . The copyright holder for this preprint (which was not certified by peer review) is the author/funder, who has granted bioRxiv a license to display the preprint in perpetuity. It is made available under aCC-BY-ND 4.0 International license.

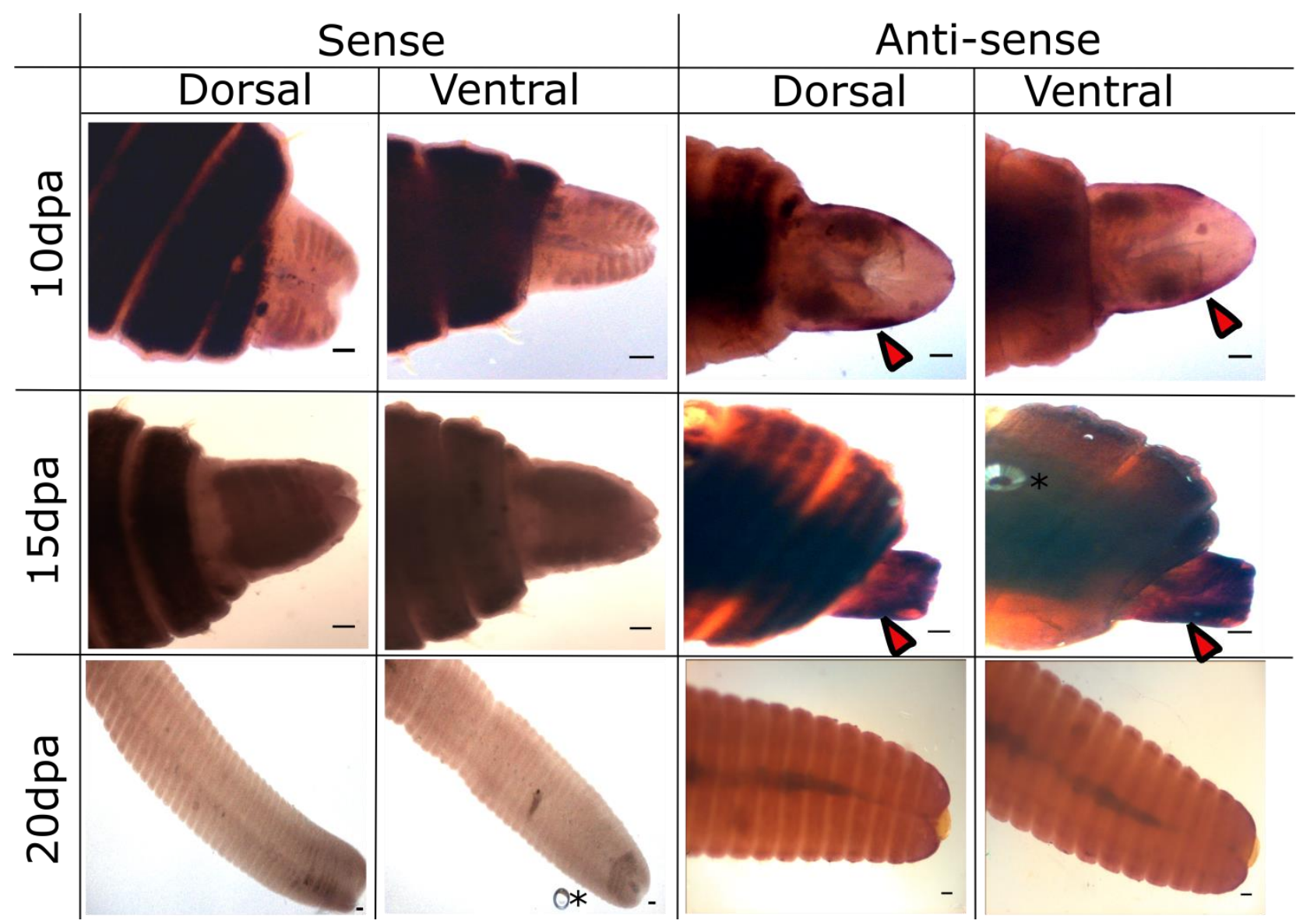


bioRxiv preprint doi: https://doi.org/10.1101/806661; this version posted October 16,2019 . The copyright holder for this preprint (which was not certified by peer review) is the author/funder, who has granted bioRxiv a license to display the preprint in perpetuity. It is made available under aCC-BY-ND 4.0 International license.

674 Expression pattern of Inc1040 in regenerating tissue

675

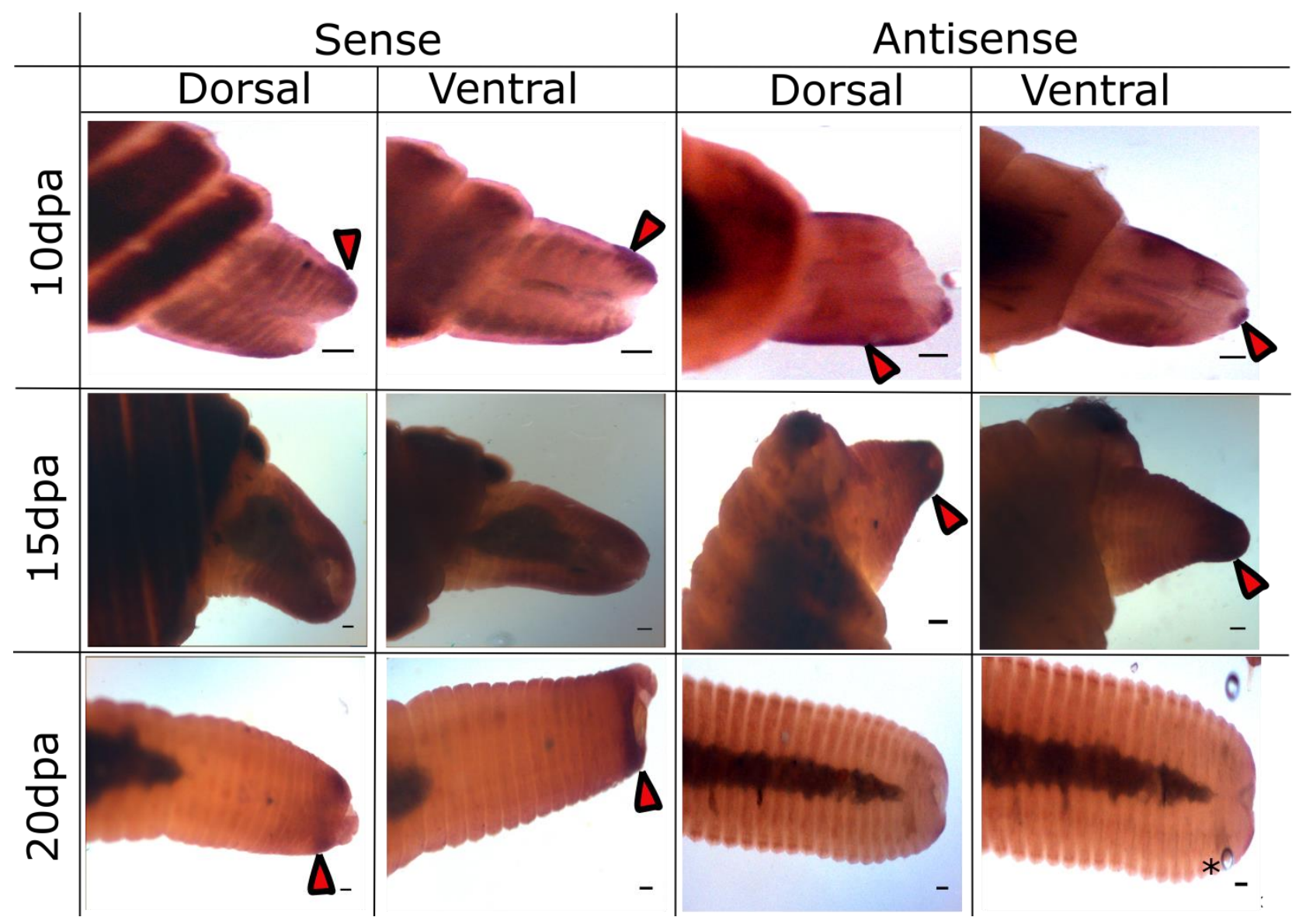


bioRxiv preprint doi: https://doi.org/10.1101/806661; this version posted October 16,2019 . The copyright holder for this preprint (which was not certified by peer review) is the author/funder, who has granted bioRxiv a license to display the preprint in perpetuity. It is made available under aCC-BY-ND 4.0 International license.

684 Table 2:

\begin{tabular}{|c|c|c|c|c|c|}
\hline & \multicolumn{5}{|c|}{ No. of binding site } \\
\hline miRNA name & Neev & $\begin{array}{l}\text { Chitin } \\
\text { synthase } \\
(\text { DN356441 | } \\
\left.6602 \text { nt }^{\star}\right)\end{array}$ & $\begin{array}{l}\text { Endochitinas } \\
\text { e } \\
(\text { DN356441 | } \\
\left.\left.2488 \text { nt }^{*}\right)\right)\end{array}$ & $\begin{array}{l}\text { Endochitinas } \\
\text { e } \\
(\text { DN319003 } \\
\left.\left.1930 \text { nt }^{\star}\right)\right)\end{array}$ & $\begin{array}{l}\text { Endochitinas } \\
\text { e } \\
(\text { DN331237 } \\
\left.2507 \text { nt }^{\star}\right)\end{array}$ \\
\hline mmu-miR-667-5p & 17 & 133 & 45 & 36 & 42 \\
\hline mmu-miR-7658-5p & 16 & 130 & 35 & 28 & 43 \\
\hline mmu-miR-7222-5p & 11 & 118 & 39 & 28 & 42 \\
\hline mmu-miR-344-5p & 5 & 97 & 29 & 25 & 39 \\
\hline
\end{tabular}

